\title{
Gender Disparities in the Labor Market in the EU
}

\author{
Dorota Witkowska
}

Published online: 6 August 2013

(C) The Author(s) 2013. This article is published with open access at Springerlink.com

\begin{abstract}
Gender equality, a policy objective of basically universal acceptance, has become a subject of interest in national governments, international organizations, research instructions, and political pressure groups. This paper reports recent investigations regarding gender disparities in the labor market. The main aim of our study is to identify factors affecting gender earning disparities in the European Union member states. Empirical research is provided in two separate areas. The first one focuses on the gender pay gap in the EU based on SES 2006 data. The second one is a detailed analysis of factors influencing wages in Poland, employing LFS 2009 data.
\end{abstract}

Keywords Labor market · Disparity · Gender pay gap

JEL J16 $\cdot$ J71

\section{Introduction}

Disparity can be identified as the condition or fact of being unequal in various situations (not having access to certain goods or services, e.g., education) or places (home, work, etc.). Labor market discrimination exists when two equally qualified individuals are treated differently solely on the basis of their individual characteristics. Inequalities in the labor market can occur in many different ways, such as by gender, sexual orientation, age, race, disabilities, religion, language, etc. (Cain 1986, p. 693) Disparity can be multidimensional and linked to inequality in skills, education, opportunities, happiness, health, life expectancy, welfare, assets, and social mobility. It is mostly measured by wage differentials, but the non-income dimension is also considered (see Heshmati (2004) as an example).

Labor market discrimination by gender, race, and ethnicity is a world-wide problem and, as Neuman and Oaxaca (2003) have claimed, estimation of various types of discrimination has become routine since the wage decomposition methodology was popularized by Blinder (1973) and Oaxaca (1973). Therefore, there is a

D. Witkowska $(\square)$

Warsaw University of Life Sciences, Warsaw, Poland

e-mail: dorota_witkowska@sggw.pl 
large amount of research concerning different types of inequalities reported in the literature. For instance, problems of racism are discussed by Bertrand and Mullainathan (2004), age discrimination by Neumark and Stock (1999), and disablism (disability discrimination) by Baldwin and Johnson (1994), among others.

Eurobarometer research has pointed out two negative phenomena: violence against women and wage inequality between women and men. Gender equality is a policy objective of basically universal acceptance and is a subject of interest in many national governments, international organizations, research institutes, and political pressure groups. The strategy for equality between women and men (2010-2015) was adopted by the European Commission on 21 September 2010. Also, the United Nations Millennium Declaration promulgates the pursuit of gender equality as one of the eight Millennium Development Goals to be reached by 2015. Problems regarding women's participation in the labor market became one of the main issues under current discussion because of the financial-economic crisis and aging of societies in developed countries.

In our research, we focus on gender wage disparities in the labor markets of European Union member countries. The paper consists of five sections based on literature reviews and my own empirical research. The first section provides a general overview on gender discrimination. Next, different measures of inequalities are presented. The section following that is dedicated to the description of the labor market in centrally-planned economies and the impact on the current situation in transitional countries. A literature review regarding gender inequality is presented in the fourth section. The last section contains some results of empirical investigations. The main aim of our analysis ${ }^{1}$ is to answer the question: What affects gender disparities in earnings? The analysis initially focuses on the European labor market as a whole. Gender pay gap (GPG) data estimated by Eurostat on the basis of metadata from the Structure of Earning Survey (SES) are provided. The paper is also concerned with the labor market in Poland that represents the largest (in terms of population, territory, and GDP) transition economy country among new European Union member states. Research is provided applying micro data from the Labor Force Survey (LFS).

\section{Gender Discrimination}

There are several indicators, such as income, employment, and social benefits, that may be examined in order to assess the relative economic situation of women. However, wages seem to be the most important determinant of economic well-being and personal success. In particular, the male-female earnings differential affects the position of women in the labor market as well as the status and power of women within the household.

Despite limited academic attention (Adamchik and Bedi 2003), the popular press and non-governmental organizations have often highlighted the importance of analyzing gender pay differences in the labor market. An assessment of this sort is important, as relatively lower wage rates for women may generate a wide spectrum of negative consequences. First, lower wage rates for women may increase the economic dependence

\footnotetext{
${ }^{1}$ Research is conducted on wage inequalities between men and women in Poland in the framework of the European Union, financed by National Science Centre grant No. 2011/01/B/HS4/06346, Poland.
} 
of women on their male partners, which in turn may increase their susceptibility to domestic violence. Second, many women are single mothers and are the sole wage earners in their families. For single mothers, adverse labor market outcomes combined with less accessible child care are likely to enhance the probability that their families live in poverty. Third, gender differences at the work place are transformed into inequality after retirement. Since, on average, women live longer than men, they are more likely to fall into poverty in their old age.

A growing area of research attempts to collect direct evidence on gender discrimination in the labor market in two main ways. First, some studies have examined whether female workers earn less than comparable male workers within the same establishments and narrowly defined occupational categories. Second, a number of studies attempt to measure productivity for female and male workers directly to determine whether gender pay differences can be directly linked to productivity differences. Research presented by Gardeazabal and Ugidos (2005) and Young and Wallace (2009) are two good examples.

Gender discrimination may take a variety of forms (McConnell and Brue 1986, p. 290; Kot 1999, p. 225-226):

1. wage discrimination when men and women who work side by side doing the same tasks equally well obtain different payment;

2. discrimination in hiring when the unemployment rate of women is significantly higher than that of men, i.e., women are the first to be fired and the last to be hired;

3. occupational segregation defined as the division of labour, as a result of which men and women are channelled into different types of occupational roles and tasks, such that there are two separate labour forces (Marshall 1998);

4. educational gender segregation (human capital discrimination) when different forms of training and education are not equally available to both genders, thereby reducing human capital (McConnell and Brue 1986, p. 289, see also Livanos and Pouliakas 2009).

The first three types of gender discrimination influence labor disparities directly when one is seeking a job, thus they are called direct or market discrimination. Human capital discrimination appears prior to entering the job market, therefore it is called indirect discrimination.

Historically, gender differences in work values, perceived as a rationalization for occupational gender segregation, have been de-emphasized in the sociological literature. More recent experimental studies in behavioral economics have noted essential differences between men and women in individual attitudes towards altruism and greed, leadership and competitiveness (Fortin 2005). It is also well known that women tend to be occupationally segregated from men and are penalized because of such segregation. Occupational segregation is mostly caused by stereotypical, biological, and social differences between genders (and races). Occupational segregation $^{2}$ is also derived from what is known as "gender essentialism", the belief that because of biological differences between men and women, they are different as far as character and personality are concerned. Gender essentialists view men as being

\footnotetext{
${ }^{2}$ Segregation arises when preconceived notions about a particular gender are carried over into the workforce, and a person's competency is based on these prejudices (i.e. thinking all women are weak and cannot engage in heavy labor).
} 
strong and powerful and women as being weak and emotional. The concentration of women in certain sectors of the economy is also called horizontal segregation. ${ }^{3}$ Vertical segregation is the concentration or over-representation of women in certain levels of the professional hierarchy. ${ }^{4}$

It is extremely difficult to explain causes and mechanisms of gender discrimination, however it is easier to define it than to measure such inequalities (Kot 1999, p. 225). The literature offers a variety of theories about how and why women face discrimination in the labor market: Becker (1957), Madden (1975), McConnell and Brue (1986), Thurow (1975), Arrow (1973), and Bergmann (1971), among others.

\section{Measurements of Inequalities}

Another important issue is the measurement of gender disparities in terms of the types of discrimination presented above. There are several gender-related indicators and gender inequality indexes. The former are represented by either the Gender-Related Development Index or the Gender Empowerment Measure introduced by the (UN) United Nations Development Programme in 1995 and their modifications, and the latter are represented by the Relative Status of Women index (Dijkstra and Hanmer 2000) and Gender Equality Index, (GDI) introduced by Social Watch in 2005 for all UN states and the one overworked by the European Institute for Gender Equality (EIGE) in 2013, or Standardized Index of Gender Equality (Dijkstra 2002). These gender inequality indicators broadly encompass different socioeconomic aspects discussed by Klasen and Schuler (2011). However, at the labor market level, the aspects generally associated with explaining the differences are (Ñopo et al. 2011):

1. personal and job characteristics of women (age, education, experience, occupation, working time, job status, type of contract),

2. labor market structure (occupational segregation by gender, level of formality), and

3. institutional, cultural, and social norms and traditions.

Some of the above mentioned aspects are not directly observable or measurable, therefore one of the main challenges is to measure this discrepancy in the labor market. Popular measurements of inequality are based on comparisons of male and female indicators regarding rates of unemployment, structure of employment in terms of management positions, and payments. ${ }^{5}$ The latter is measured in several ways, for instance Becker (1957) introduced the discrimination coefficient $d$ :

$$
d=\frac{W M}{W F}-1 \text { or } d \%=\left(\frac{W M}{W F}-1\right) \cdot 100
$$

\footnotetext{
${ }^{3}$ With horizontal segregation, occupational gender segregation occurs as men and women are thought to possess different physical, emotional, and mental capabilities. These different capabilities suggest the genders vary in the types of jobs they are suited for. This can be specifically viewed with the gendered division between manual and non-manual labor.

${ }^{4}$ With vertical segregation, occupational gender segregation occurs as occupations are stratified according to the power, authority, income, and prestige associated with the occupation and women (or men) are excluded from holding such jobs.

${ }^{5}$ We just mention some examples.
} 
where: $W M$ and $W F$ represent real earnings of male and female paid employees, respectively.

In other words, the female to male wage ratio is: $\frac{W F}{W M}=\frac{1}{1+d}$. If the discrimination coefficient $d$ equals 0.5 , it means that (due to the Becker theory) the employer will hire women if men earn $50 \%$ more than women, i.e., the wage ratio: $\frac{W M}{W F}=\frac{3}{2}$.

Another payment discrimination measure was proposed by Oaxaca and Ransom (1994):

$$
D=\frac{\frac{W M}{W F}-\frac{W M^{0}}{W F^{0}}}{\frac{W M^{0}}{W F^{0}}}=\left(\frac{W M}{W F}-\frac{W M^{0}}{W F^{0}}\right) \cdot \frac{W F^{0}}{W M^{0}}=\frac{W F^{0}}{W M^{0}} \cdot \frac{W M}{W F}-1
$$

where: $W M^{0}$ and $W F^{0}$ represent the hypothetical earnings of male and female paid employees when there is no gender discrimination, respectively. $W M$ and $W F$ represent real earnings, as previously.

If $D=0$, there is a lack of discrimination. For $D>0$, women earn less than men. The situation is the opposite for $D<0$, however, this situation is rarely observed. ${ }^{6}$ Here the question arises how to evaluate the hypothetical earnings of male and female employees when there is no gender discrimination. Neumark (1988), Cotton (1988), Oaxaca (1973), as well as Oaxaca and Ransom (1994) have suggested some more or less arbitrary solutions. Kot (1999) evaluated $W M^{0}$ and $W F^{0}$ directly on the basis of a survey by asking employee respondents about the:

- minimum wages they are ready to accept in their current positions, with that value treated as their productivity self evaluation, and

- maximum wages which they can offer for a certain position regardless of the gender of the employee.

Similar to the payment discrimination coefficient is the so-called gender pay gap $(G P G)$, evaluated by Eurostat using data from the Structure of Earnings Survey. GPG is defined as follows:

$$
G P G_{i}=\frac{G H W M_{i}-G H W F_{i}}{G H W M_{i}} \cdot 100=\left(1-\frac{G H W F_{i}}{G H W M_{i}}\right) \cdot 100
$$

where for each $i$-th country or region, $G H W M_{i}$ is the average gross hourly earnings of male paid employees and $G H W F_{i}$ is the average gross hourly earnings of female paid employees.

The GPG represents the difference between average gross hourly earnings of male and female employees as a percentage of average gross hourly earnings of male paid employees. From reference year 2006 onwards, the new GPG data is based on the methodology of the Structure of Earnings Survey carried out once every four years. The most recently available reference years are 2002 and 2006, and Eurostat computed the GPG for these years on this basis. ${ }^{7}$ For the intermediate years $(2007$ onwards), countries provide Eurostat with estimates benchmarked on the SES results.

\footnotetext{
${ }^{6}$ We reported such cases in: Fernández-Avilés et al. (2010), as well as in Matuszewska-Janica and Witkowska (2010).

${ }^{7}$ SES results from 2010 has been not available yet.
} 
Table 1 contains a comparison of GPG evaluated for 27 EU member states for 2006 and 2011. It is obvious that the average for Europe decreased from 18.4 in 2006 to $16.2 \%$ in 2011. However, in some countries, the gender pay gap increased in 2011 in comparison to 2006 (i.e., in Belgium, Greece, Italy, Portugal, Bulgaria, Hungary, Malta, and Romania). In 2011, the smallest wage disparities were observed in Slovenia (2.3\%), Poland (4.5\%), and Italy (5.8 \%) while the biggest were in Estonia (27.3\%), Austria (23.7\%), Germany $(22.2 \%)$, and Greece $(22 \%)$.

Other important issues include the economic activity of Society and the structure of employment. Measures that are used most often to describe the labor market are activity (participation) and employment rates. According to the Eurostat definition, the economically active population (labor force) encompasses all persons aged 15-64 whether employed or unemployed. Therefore, activity is defined as the share of the number of active persons in the whole population in the same age group, i.e.:

$$
R A_{i l}=\frac{N A_{i l}}{N W_{i l}} \cdot 100
$$

where: $N A_{i l}$ and $N W_{i l}$ represent counts of economically active persons and the whole population belonging to the $l$-th age group in the $i$-th country, respectively.

Table 1 Employment rate (6) and gender pay gap (3) for women evaluated in the years 2006 and 2011

\begin{tabular}{|c|c|c|c|c|c|c|c|c|c|}
\hline \multicolumn{2}{|l|}{ Region or country } & \multirow{3}{*}{$\begin{array}{l}R W_{i} \\
2006 \\
2\end{array}$} & \multicolumn{2}{|l|}{$G P G_{i}$} & \multicolumn{2}{|l|}{ Country } & \multirow{3}{*}{$\begin{array}{l}R W_{i} \\
2006 \\
2\end{array}$} & \multicolumn{2}{|l|}{$G P G_{i}$} \\
\hline & & & 2006 & 2011 & & & & 2006 & 2011 \\
\hline 1 & & & 3 & 4 & 1 & & & 3 & 4 \\
\hline European Union & EU27 & 8.07 & 18.4 & $16.2^{\mathrm{p}}$ & Bulgaria & BG & 2.0 & 12.4 & 13.0 \\
\hline Austria & AT & 21.13 & 25.5 & $23.7^{\mathrm{e}}$ & Czech Republic & $\mathrm{CZ}$ & 13.30 & 23.4 & 21.0 \\
\hline Belgium & $\mathrm{BE}$ & 17.58 & 9.5 & 10.2 & Cyprus & $\mathrm{CY}$ & 5.18 & 21.8 & $16.4^{\mathrm{p}}$ \\
\hline Denmark & DK & -2.54 & 17.6 & 16.4 & Estonia & $\mathrm{EE}$ & -18.33 & 30.3 & 27.3 \\
\hline Finland & FI & -4.64 & 21.2 & $18.2^{\mathrm{p}}$ & Hungary & $\mathrm{HU}$ & 0.64 & 14.4 & 18.0 \\
\hline France & FR & 10.44 & 15.4 & $14.7^{\mathrm{p}}$ & Latvia & LV & -10.97 & 15.1 & 13.6 \\
\hline Germany* & $\mathrm{DE}$ & 12.22 & 22.7 & $22.2^{\mathrm{p}}$ & Lithuania & LT & -4.89 & 17.1 & 11.9 \\
\hline Greece & GR & 14.80 & 20.7 & $22.0^{\mathrm{a}}$ & Malta & MT & 26.43 & 5.2 & 12.9 \\
\hline Italy & IT & 15.24 & $4.4^{\mathrm{c}}$ & 5.8 & Poland & PL & 5.66 & 7.4 & 4.5 \\
\hline Ireland & IE & -1.75 & 17.2 & $13.9^{\mathrm{b}}$ & Romania & RO & 7.57 & 7.8 & 12.1 \\
\hline Luxembourg & LU & 28.87 & 10.7 & $8.7^{\mathrm{p}}$ & Slovenia & SI & 7.00 & 8.0 & 2.3 \\
\hline Netherlands & NL & 7.04 & 23.6 & 17.9 & Slovakia & SK & 3.54 & 25.8 & 20.5 \\
\hline Portugal & PT & 3.07 & 8.4 & 12.5 & & & & & \\
\hline Spain & ES & 18.57 & 17.9 & $16.2^{p}$ & & & & & \\
\hline Sweden & $\mathrm{SE}$ & -2.58 & 16.5 & 15.8 & & & & & \\
\hline United Kingdom & UK & -0.23 & 24.3 & 20.1 & & & & & \\
\hline
\end{tabular}

Columns 273 Matuszewska-Janica and Witkowska (2010), columns 4 Eurostat

*Germany (until 1990 former FRG), p: provisional data, e: estimated data, a, b: data from 2008 to 2010 respectively 
The employment rate is calculated by Eurostat by dividing the number of employed persons aged 20 to 64 by the total population of the same age group:

$$
R E_{i l}=\frac{N E_{i l}}{N W_{i l}} \cdot 100
$$

where $N E_{i l}$ and $N W_{i l}$ represent counts of employed persons and the whole population belonging to the $l$-th age group in the $i$-th country, respectively. Both measures may be calculated for the whole population and for men and women separately, as well as for different age groups, etc.

Figures 1 and 2 show the overall employment rate for the EU and the female employment rate (5). An economic crisis is clearly visible in 2008-2010 when the employment rate decreased, although it had an increasing tendency from the beginning of the millennium. Beginning in 2010, we have noticed a stabilization tendency in the labor market in Europe. Women's participation in the labor market systematically increased. The difference between employment rates for the European population in total and for women decreased from $7.6 \%$ in 2003 to $5.6 \%$ in 2012 (Fig. 1). The average female employment rate in 27 EU member states was $58.6 \%$ in year 2012 (i.e., nearly $59 \%$ of women aged 20-64 were employed.) The highest female employment rate $(70 \%)$ was observed in Scandinavian countries and the Netherlands while the lowest (below 50 \%) was observed in Southern Europe (i.e., Greece, Malta, and Italy) (Fig. 2). ${ }^{8}$

It is also possible to measure women's participation in the labor market, defined as the female employment rate, using a measure that describes the structure of employment by comparing the differential between male and female employment, with the following formula:

$$
R W_{i}=\frac{N M_{i}-N F_{i}}{N M_{i}+N F_{i}} \cdot 100=\frac{N M_{i}-N F_{i}}{N W_{i}} \cdot 100
$$

where: $N M_{i}, N F_{i}$, and $N W_{i}$ are counts of employed men and women and the whole population in the $i$-th state, respectively.

Since $N M+N F$ is total employment, the female employment rate is the percentage excess of male employees in the labor market when $R W>0$, and describes the opposite situation when $R W<0$. If $R W=0$ the number of men and women in the labor market is the same.

In international and temporal comparisons, the measures presented above are additionally described by subscripts (or superscripts) for $j$-th economic sector, $k$-th job seniority group, the $l$-th age group, the $t$-th period of time, etc. ${ }^{9}$ For example:

$$
R W_{i t}=\frac{N M_{i t}-N F_{i t}}{N M_{i t}+N F_{i t}} \cdot 100
$$

\footnotetext{
${ }^{8}$ The distributions of overall employment rates for men and women combined for 2012 are similar. See also Teichgraber (2012) for a similar analysis based on data from the European Union Labour Force Survey for 2011.

${ }^{9}$ Depending upon the type of analysis, one might consider for inclusion economic branches, age, working time, job status, type of contract, etc.
} 


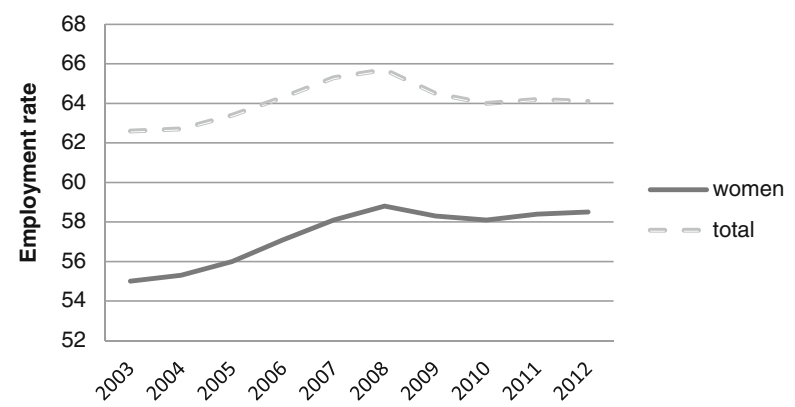

Fig. 1 Changes in the employment rate (for individuals ages 20-64) in the European Union (27 member states) for 2003-2012. Source: Eurostat

describes the structure of employment in the $i$-th country or region and the $t$-th period of time, since $N M_{i t}$ and $N F_{i t}$ are counts of men and women employed in the $i$-th country or region and the $t$-th period of time, respectively.

The female employment rate (6) evaluated for 27 EU states in 2006 is presented in Table 1. Notice that in Northern Europe, there are more women than men among

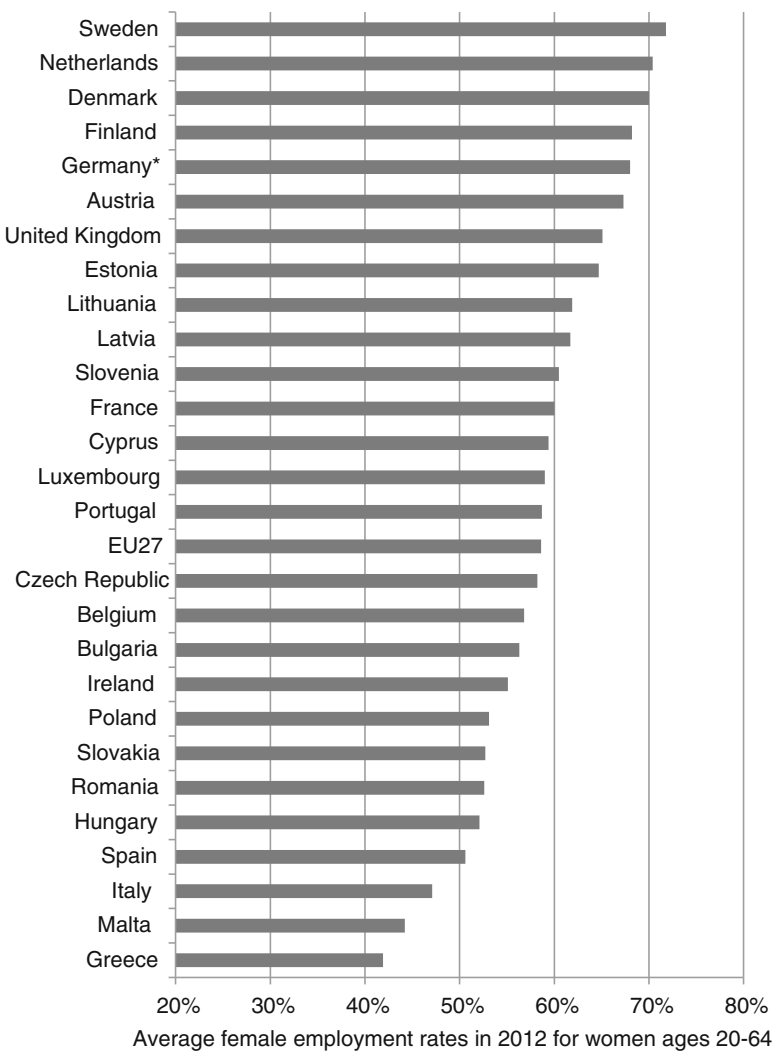

Fig. 2 Female employment rate (for women ages 20-64) in 2012. Source: Eurostat. Note: Germany* until 1990 former FRG 
employees. In Scandinavian countries, the UK, and Lithuania, the excess of female employees is smaller than $5 \%$, while in Estonia and Latvia, the measure (6) equals $18 \%$ and $11 \%$ respectively. The biggest excess of male employees is observed in Luxemburg (29\%), Malta (26\%) and Austria (21\%) while for the whole European Union it is $8 \%$.

Another measure describing the structure of employment is the feminization rate:

$$
F E M_{i j}=\frac{N F_{i j}}{N M_{i j}+N F_{i j}} \cdot 100=\frac{N F_{i j}}{N W_{i j}} \cdot 100
$$

which represents the share of women working in the $j$-th economic branch in the $i$-th country. Analysis of that rate depicts whether sectorial segregation exists.

The analysis of wage differences between men and women has recently emerged as one of the core questions in labor market research, mainly due to increasing participation of women in the labor market (see Figs. 1 and 2). In fact, according to the 2008 European Commission Report on equality between women and men, quantitative progress has been made in connection with the European strategy for growth and jobs. However, efforts are still needed to boost the qualitative aspect of equality. Moreover, the objective of eliminating gender gaps in employment must be continued and intensified by tackling labor market segregation.

\section{Labor Market Under Communism and its Impact on the Current Situation in Transitional Economies}

Central and Eastern European states have experienced an essential change in their political and economic structures since 1989, when radical reforms started in Poland that were followed by other countries belonging to the former Soviet bloc (Keane and Prasad 2006). The privatization of state owned enterprises and implementation of market mechanisms were the main goals of reform introduced in post-communist countries. The transition also involved significant changes in labor market institutions. Constraints on layoffs and redundancies were significantly reduced and unemployment appeared. There has also been a massive inter-sectoral labor reallocation. The rapid rise of the private sector (which is far less unionized than the public sector and much less subject to regulations in terms of wage setting) has also resulted in greater labor market "flexibility" in many dimensions. Very generous pensions led massive numbers of older workers to take early retirement during the early phase of the transition. ${ }^{10}$

The socialist countries of Eastern Europe and the former Soviet Union were long committed, at least nominally, to gender equality in the labor market (Brainerd 2000). Government policies such as relatively high minimum wages and generous maternity leave and day care benefits encouraged women to work, and female labor force participation rates were high compared with those of other countries. Though women remained over-represented in areas such as health and education, they fared at least as well as their counterparts in most developed and developing countries in terms of female-male wage differentials.

\footnotetext{
$\overline{10}$ This statement is true at least for Poland.
} 
In centrally planned economies, wages were assigned according to occupational wage scale within each industry. Enterprises operating without competitive pressure had little control over wage rates and wage differentials. There was no unemployment in the sense of joblessness, however work efficiency was very low and many job positions were completely useless. Women were accorded a wide range of rights and privileges at work, such as fully paid maternity leave, legal protection from overly physical and dangerous work during pregnancy, and easy access to nursery schools and health care facilities that were located in larger enterprises.

In terms of occupations and industry branch, women and men were segregated in a similar way as in the West. It is worth mentioning that in many centrally planned economies, women's labor market participation rates were higher than in Western states. The main reason was the low labor market wages per employee which was not enough to maintain a basic living standard, forcing both adults in a nuclear family to work. Relatively few women held senior positions since women undertook a very large share of domestic duties, thus incurring a double burden and leaving them less time to pursue a career than men. Also, the revolution in gender relations in the West, which has brought about a slow but fundamental shift in the household division of labor, did not happen in communist countries.

The liberalization of the wage setting system, prices, and trade during the transition toward a market economy has changed this picture dramatically. Enterprises have gained some control over wages on the one hand, and have faced rising competition on the other. These peculiar changes in labor market institutions and competitive environments challenge the existing theory of discrimination (Grajek 2001). One might expect gradual driving out of discrimination according to Becker's (1957) classical model and the "overcrowding" model of Bergmann (1974). On the other hand, discrimination should survive or even strengthen according to "statistical discrimination" models (e.g., Aigner and Cain 1977).

According to UNICEF data (1999), female labor market participation has been falling in many transitional economies since 1989. The scale of the collapse in participation rates during the transition period was very large. For example, in Poland, about one and a half million female jobs disappeared between 1989 and 1994 (Newell and Barry 2001).

The welfare of both men and women crucially depends on the rate at which the transitional economies recover and develop. Labor market earnings remain a key important component of household income in all the transitional economies and provide a direct link between household welfare and economic activity. As a result of economic and political transformation in European post-communist states, ${ }^{11}$ analyses that are conducted for Europe are usually provided separately for transitional and developed economies. Differences in the situation of women in Eastern and Western Europe with respect to motivation for entering the labor market were diametrically opposed. The situation in post-communist countries has been discussed

\footnotetext{
${ }^{11}$ Post-communist countries are also identified as Central and Eastern Europe (CEE), however such analyses also cover countries that were former Soviet Union Republics which are located in Central Asia. The reforms in other former Soviet Union Republics have not been profound enough and they are treated as a different class of countries that are usually identified with The Commonwealth of Independent States (CIS) with the exception of Baltic states (Lithuania, Estonia and Latvia) that transformed their economic and political systems toward the market-oriented economies and became members of European Union.
} 
by Klasen (1994), Newell and Barry (2001), Keane and Prasad (2006), Lehmann and Wadsworth (2001), among others. Plasman and Sissoko (2004), Arumpalam et al. (2004), Amuedo-Dorantes and de la Rica (2005), and Daly et al. (2006) have focused on the situation in well-developed states.

\section{Results of Recent Studies}

The profound discussion about the research provided on gender earning gaps is presented in Ñopo et al. (2011). Published investigations on gender discrimination and wage discrepancy have shown that generally,

- there is no relationship between economic growth and the narrowing of earnings gaps for women (Hertz et al. 2008; Blau and Kahn 2001; Tzannatos 1999);

- other reasons that have been found to be linked to gender earnings disparities are: sectorial segregation to lower wage sectors against women (Tzannatos 1999), lower female net supply and wage structure (Blau and Kahn 2001), labor market liberalization, and institutional framework in each country (Weichselbaumer et al. 2007; Blau and Kahn 2001; Cornish 2007 and Tzannatos 1999), among others.

Christofides et al. (2010) discussed the empirical results of the gender wage gap analysis for a set of 24 EU member states, applying different methods of analysis such as quantile regression and probit models (Oaxaca and Ransom 1994), decomposition (Olivetti and Petrongolo 2008), selection procedures, among others. They did so by using characteristics such as education, firm size, marital status, industry of employment, age or experience, number of children, income from property rents, financial assets and other allowances, mortgage expenses, child-care provisions, and occupation. Employing Oaxaca and Ransom decomposition, the total wage gap was divided into the explained portion that measures the part of the predicted average wage difference that can be explained by the difference between the male and female characteristics, and the unexplained part that corresponds to the male advantage and female disadvantage. The unexplained part of the gender pay gap is identified as gender earnings discrimination, since the explained part describes differences in wages caused by such factors as education, firm size, marital status, industry of employment occupation, experience, etc. The authors show that a large part of the wage gap is not explained by employing these features. They also conclude that in several countries the unexplained gap is larger than the total, suggesting that female characteristics are superior to male ones (for instance, women are better educated than men). When decomposition is performed across the wage distribution (using quantile regression), the unexplained gender wage gap widens at the top of the distribution (the so-called glass ceiling effect) in the majority of countries and, in some cases, it also widens at the bottom of the distribution (the socalled sticky floor effect). The wage gap is wider when non-random selection into work is taken into account; this suggests that women in the selected samples are more highly qualified than in the population at large. There is some evidence that countries with more generous work-family reconciliation policies tend to have stronger glass ceiling and sticky floor effects.

Matuszewska-Janica and Witkowska (2010 and 2011) investigated relations among the gender structure of employment and the gender pay gap in different age 
classes and economic branches for 27 European Union member states applying data from SES 2006. The results of the Pearson linear correlation coefficient evaluation and verification of statistical significance point out negative and significant correlation between the female employment rate $R W(6)$ and gender pay gap $G P G$ (3) for total employment and for employees ages 30-39 years. ${ }^{12}$ They also show that the structure of employment in 10 post-communist countries (NM10) significantly differs from the one observed in EU15, i.e., old EU states for total employment and in the age groups of employees who are from 30 to 59 years old. The gender pay gap is significantly smaller in NM10 in groups of employees less than 40 years old and bigger for the group of oldest workers that might be the effect of female early retirements in the beginning of the transformation period. ${ }^{13}$

For Western European states, some literature shows that wage differentials are mainly explained by female segregation into low-wage jobs (Daly et al. 2006), but the existence of significant inter-industry wage differentials ${ }^{14}$ in all countries for both sexes has also been documented (Gannon et al. 2007). There are also studies that support the idea that gender pay gaps are typically bigger at the top of the wage distribution and that the gender pay gap differs significantly across the public and private sector wage distribution of each country (Arumpalam et al. 2004).

With respect to the European and Central Asian economies in transition, authors agree on the relative improvement of female wages in most countries of the region. The results indicate a consistent increase in female relative wages across Eastern Europe, and a substantial decline in female relative wages in Russia and the Ukraine. Increased wage inequality in Eastern Europe has also depressed female relative wages, but these losses have been more than offset by gains in rewards based on observed skills and by an apparent decline in discrimination against women (Brainerd 2000). Still, female segregation into low-wage occupations emerges as the main contributor to the gender pay gap (Simón 2007). State-owned enterprise wages are higher than those in the private sector. Further, while wages of men and women are at parity in the public administration sector, there is a large gender wage-gap in the private sector in favor of men (Tansel 2004). In general, the pay gap between men and women in transitional countries is low by international standards, although there is documented evidence of larger gaps in the higher paid jobs relative to the lower paid jobs (Newell and Barry 2001). However, Klasen (1994) warns, “...women may be the biggest losers of the monumental economic changes taking place in the former communist block. In particular, they may lose much of the economic and social independence they achieved as a result of their high involvement in the labor market."

On the basis of observations made in East Germany during the first years of transition, Hunt (1998) noticed that four-fifths of the women's wage rise was attributable to a selection effect caused by the withdrawal from employment of poorly qualified women. Hunt's findings for former East Germany seem to be atypical, since

\footnotetext{
${ }^{12}$ For employees in the age group 40-59, rejection of the null hypothesis is possible only for the significance level $\alpha=0.1$ and there is no correlation for the youngest and oldest employees.

${ }^{13}$ The policy of early retirements was introduced in Poland (and probably other countries) to decrease high unemployment that appeared in the first years of transition.

${ }^{14}$ Plasman et al. (2006); Gannon et al. (2007), Du Caju et al. (2011) have documented inter-industry wage differences.
} 
the departure from the German labor market of poorly qualified women is facilitated by the existence of a much more generous social safety net in Germany than is currently in existence in other transitional countries.

Considering economic and political transformation in Poland, Grajek (2001) claimed that the year that the communists left power (1989) turned out to be far more important in terms of improving the relative position of women than the actual year of launching the reform package (1990) and all the following transition years. Females gained substantially due to the structural shift in the very first years of the new economic system. The improvements slowed down or even reversed in the following years, probably due to statistical discrimination.

Adamchik and Bedi (2003) examined gender differences in a variety of labor market outcomes with an emphasis on the gender wage gap in Poland during 19931997. During this period, the empirical analysis shows there was a marked decline in relative employment outcomes for women while industrial and occupational segregation remained unchanged. The mean gender wage gap of about $22-23 \%$ remained steady and, except for a reduction at the lower tail, remained stable throughout the wage distribution.

Wage gap decompositions show that between 50 and $60 \%$ of the wage differential in Poland could be explained by differences in observed characteristics. Most of these differences were attributed to the industrial and occupational affiliation of women. Although the effect of industrial and occupational segregation on wages forms part of the so-called explained portion of the wage gap, it may also be viewed as a consequence of pre- and post-labor market discrimination based on gender stereotyping. Throughout the period, a large portion of the wage gap remains unexplained.

The stability of the gender wage gap in Poland suggests that the factors responsible for determining wage gaps between men and women and the labor market status of women in general have not changed. The perception of women belonging to certain educational, occupational, and industrial streams persists. This perception is echoed and supported by labor legislation that prevents women from working in occupations and sectors that are considered inimical to their health. The view that women are primarily responsible for child care and that this responsibility lowers their job performance also appears to persist. Thus, it seems that stereotypes about women are very deeply ingrained and have not been influenced by the systemic changes in the political and economic system in Poland.

Keane and Prasad (2006) examined the evolution of the structure of labor earnings in Poland over the period 1985-1996 using micro data from the Polish Household Budget Surveys. The relatively long span of the dataset allowed them to track changes for an extended period leading up to and following the "big bang". They found that overall earnings inequality rose markedly during the transition period of 1989-1996. Keane and Prasad also conducted a detailed examination of the sources of the increase in earnings inequality. Prior to the transition, the wage structure in Poland was highly compacted, with wages of college-educated white-collar workers very similar to those of manual workers. A common view is that the rise of the private sector, in which there is competitive wage setting and, hence, a more unequal wage distribution, is the main source of increasing earnings inequality during transition. Yet, the results obtained by the authors contradict this view. 
In Poland, earnings inequality is indeed higher in the private sector (e.g., the log 9010 earnings differential in 1996 was 1.19 in the private sector and 1.05 in the public sector), and the private sector share of (non-agricultural) employment increased from $5 \%$ in 1988 to $39 \%$ in 1996. Still, Keane and Prasad found that reallocation of labor from the public to the private sector accounted for only $39 \%$ of the total increase in earnings inequality (as measured by the change in the variance of log earnings).

The majority of the increase in earnings inequality during the Polish transition (52\%) was due to increased wage variance within both the public and private sectors. That is, earnings inequality within both the private and public sectors grew substantially, and by similar amounts. This is consistent with the view that even state-owned enterprises in Poland have engaged in substantial restructuring, as suggested by Pinto et al. (1993). Consistent with their finding of increased earnings inequality within the public sector, Commander and Dhar (1998) reported a substantial increase in the heterogeneity of wages across SOEs between 1990 and 1994, with those that performed better in terms of sales offering higher wages. Keane and Prasad also found that educational wage premiums increased substantially. Nevertheless, the majority of the increase in overall earnings inequality $(60 \%)$ in Poland is attributable to changes in within-group inequality. A striking result is that increases in within-group inequality were concentrated among workers with higher levels of formal education. This is quite different from the patterns documented for the U.S. and the UK of sharp increases over the last two decades in between-group inequality at all levels of education (Keane and Prasad 2006).

Newell and Socha (2007) have demonstrated that the private sector in Poland tends to pay more unequally than the state sector, and since there was a surge of privatization during 1998-2002, this contributed to the rise in wage inequality. It is also true that inequality, in the form of hourly wage variance and regression wage premiums to education and occupation, is consistently higher and in the case of education premiums rose more quickly in the private sector data. Witkowska (2012) analyzed factors influencing monthly earnings obtained by men and women in 2005 and 2009, applying exponential and multinomial logit models that were estimated on the basis of Polish Labour Force Survey. She found a gender wage gap in both years. The main difference between the situations observed in 2005 and 2009 was that individuals working for private enterprises rated their wages lower than employees from public institutions in 2005, while in 2009 the situation was the opposite. Regardless of year of investigation, women working in private institutions were better paid than women in public institutions, although this variable was significant in 2009 only. In 2005, men working for public institutions earned more than the ones working for private firms. Employees from the biggest cities earned significantly more than the ones from the countryside. Respondents living in towns up to ten thousand inhabitants declared lower wages than employees from villages in 2009 . For 2005 , the parameter representing this variable was statistically insignificant.

\section{Results of Empirical Analysis}

There are many factors influencing wages that are either connected with the individual attributes of employees or describe the general situation in the labor market and characterize the particular place (institution) of employment. The 
former may be the subject of potential wage disparities. An analysis of factors affecting gender wage inequality is provided applying regression models that are estimated on the basis of two data sets. ${ }^{15}$ The first one contains metadata from the Structure of Earnings Survey for 2006, i.e., the last available data. The statistics of the SES (carried out every four years) refer to enterprises operating in the EU with at least 10 employees in areas of economic activity defined by sections C-O (2006) of NACE Rev.1.1.(see Table 2). The second set consists of micro data from the Polish Labour Force Survey (PLFS) Q1 2009. PLFS is part of the European Union Labour Force Survey (EU LFS), a large household sample survey providing quarterly results on labor participation for people aged 15 and over as well as persons outside the labor force.

It is worth mentioning that LFS is a survey of individuals while SES is a survey of enterprises. Both surveys contain information about labor and earnings, however the focus of the research differs. In other words, SES and EU LFS contain data that differ from the point of view of the analyzed period, source of information, and therefore the information itself. For instance, information about wages and working hours in SES is given by the enterprise. In the LFS, it comes from the respondent who declares both income and working time. Information about payments appears more reliable in SES than EU LFS, but in SES there is no information about individuals working in small enterprises (i.e., less than 10 employees) and non-active persons or employee family situation, factors also important in gender disparity analyses.

The constructed models describe either disparities between hourly wages (in the EU) obtained by men and women or monthly wages (in Poland). Explanatory variables were selected based on a literature review and data availability.

\section{Models Estimated on the Basis of SES Data}

In our research, we estimate several models describing disparities $G P D_{i j k}$ between hourly wages obtained by men and women in European Union member states. We use two measures describing the wage gap in the $i$-th state, the $j$-th economic branch, and the $k$-th job seniority group: gender pay gap $G P G_{i j k}$ and gender pay convergence $G P C_{i j k}$ coefficient:

$$
G P G_{i j k}=\frac{G H W M_{i j k}-G H W F_{i j k}}{G H W M_{i j k}}=\left(1-\frac{G H W F_{i j k}}{G H W M_{i j k}}\right)
$$

\footnotetext{
${ }^{15}$ Eurostat collected data from the 27 Member States of the European Union, three candidate countries and three countries of the European Free Trade Association. The research was conducted by national statistical institutes across Europe and centrally processed by Eurostat: using the same concepts and definitions, following International Labour Organisation guidelines, using common classifications (NACE (in French: Nomenclature statistique des Activités économiques dans la Communauté Européenne)-Statistical Classification of Economic Activities in the European Community, ISCO-International Standard Classification of Occupations, ISCED International Standard Classification of Education, NUTS Nomenclature of Territorial Units for Statistics), recording the same set of characteristics in each country.
} 
Table 2 Classification of economic activities in the European Community: NACE 1.1

\begin{tabular}{ll}
\hline Code & Description \\
\hline C & Mining and quarrying \\
D & Manufacturing \\
E & Electricity, gas and water supply \\
F & Construction \\
G & Wholesale and retail trade, repair of motor vehicles, \\
& motorcycles and personal and household goods \\
H & Hotels and restaurants \\
I & Transport, storage and communication \\
J & Financial intermediation \\
K & Real estate, renting and business activities \\
L & Public administration and defence, compulsory social \\
M & security \\
$\mathrm{N}$ & Education \\
$\mathrm{O}$ & Health and social work \\
\hline
\end{tabular}

Eurostat

$$
G P C_{i j k}=\frac{G H W F_{i j k}}{G H W M_{i j k}}=1-G P G_{i j k}
$$

where: $G H W M_{i j k}$ and $G H W F_{i j k}$ represent average gross hourly earnings of male and female paid employees, respectively, while $i, j, k$ are defined as above.

Table 3 Levels of education ISCED 1997

Level Description

ISCED1 Primary education

ISCED2 Lower secondary education

ISCED3 Upper secondary education corresponds to the final stage of secondary

ISCED4 Post-secondary non-tertiary education

ISCED5A Tertiary-type A programs are largely theory-based and are designed to provide sufficient qualifications for entry to advanced research programmes and profes sions with high skill requirements, such as medicine, dentistry or architecture.

ISCED5B Tertiary-type B programs are typically shorter than those of tertiary-type A and focus on practical, technical or occupational skills for direct entry into the labor market, although some theoretical foundations may be covered in the respective programs.

ISCED6 Advanced Research Qualifications refer to tertiary programs that lead directly to the award of an advanced research qualification, e.g., Ph.D.

http://www.uis.unesco.org/Education/Pages/international-standard-classification-of-education.aspx 


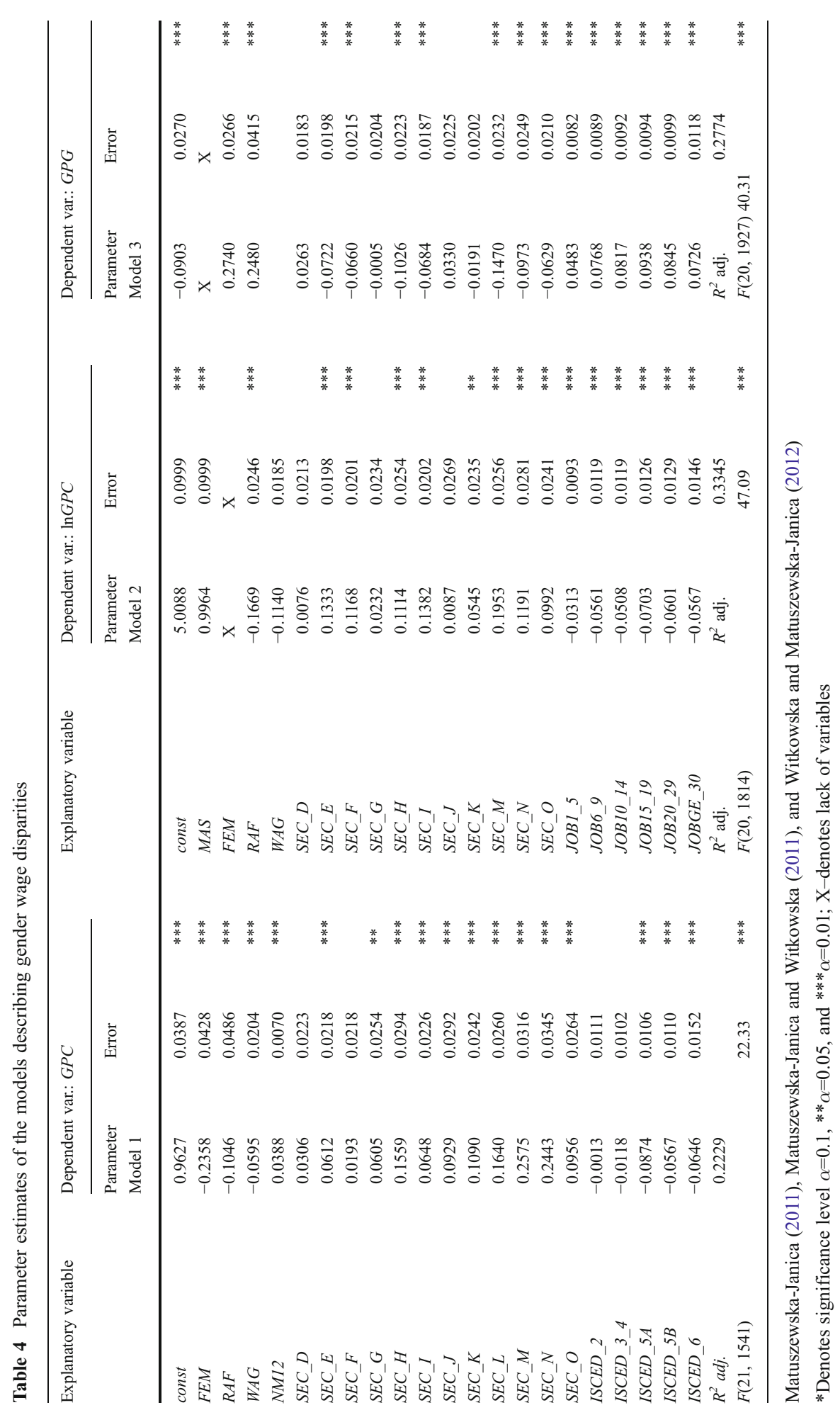


For econometric analysis, we select following variables:

1. The activity rate (4) evaluated for women, i.e.:

$$
R A F_{i}=\frac{N A F_{i}}{N W F_{i}}
$$

where for the $i$-th country: $N A F_{i}$ and $N W F_{i}$ represent counts of active women and of the whole female population ages 15-64, respectively.

2. Feminization $\left(F E M_{i j k}\right)$ or masculinization $\left(L M A S_{i j k}\right)$ rates measure employment structure are defined as follows:

$$
\begin{aligned}
& F E M_{i j k}=\frac{N F_{i j k}}{N M_{i j k}+N F_{i j k}}=\frac{N F_{i j k}}{N W_{i j k}} \\
& L M A S_{i j k}=\frac{\ln N M_{i j k}-\ln N F_{i j k}}{\ln \left(N M_{i j k}+N F_{i j k}\right)}
\end{aligned}
$$

where: $N M_{i j k}, N F_{i j k}$ and $N W_{i j k}$ represent counts of employed men and women, and all employees, for the $i$-th country, the $j$-th economic sector and the $k$-th job seniority group, respectively.

3. Economic branch wage proportion $\left(W A G_{i j}\right)$ provides information regarding the structure of hourly earnings in the $j$-th NACE branches in every country:

$$
W A G_{i j}=\frac{G H W_{i j}}{G H W_{i}}
$$

where $G H W_{i j}$ and $G H W_{i}$ represent average gross hourly earnings in the $j$-th NACE branch and the whole national economy, respectively.

4. Branch (SEC_code) is described by binary variables defined for NACE codes: D, E, F, G, H, I, J, K, M, N, O, while SEC C is the referent (see Table 2).

5. Job seniority group (JOByearl_year2) is described by binary variables distinguishing for six intervals of length of service (in the enterprise) beginning from one to five years of service, ending on the interval constructed for those individuals who worked 30 years and more (JOB30_more). The referent variable reflects employees working less than one year $\left(J O \bar{B} 0_{-} 1\right)$.

6. Country dummy (NM12) distinguishes old from new EU member states, $N M 12=1$ for new EU members and $N M 12=0$ for old EU15 countries.

7. Education of employees (ISCED_code) is considered binary, defined for five levels of education (see Table 3 ) from lower secondary education (ISCED_2) to advanced research qualifications (ISCED_6). The referent variable is primary education (ISCED_1).

Among estimated ${ }^{16}$ models, we select only the three that seem to best explain gender disparities in the European Union (Table 4). The first one (denoted as Model 1) describes $G P C$ (10) in different economic branches. From the model analysis, we can see that increasing the number of women active in the labor market decreases the

\footnotetext{
${ }^{16}$ Models are estimated applying GLS with heteroscedasticity correction (GRETL). Presented versions of the models contain only statistically significant variables.
} 
gender wage convergence. Also, increasing the feminization rate and wage proportions in the $j$-th branch negatively influences GPC. In other words, the gender pay gap is bigger in those economic sectors with higher feminization rates and where wages are bigger than average. The difference in earnings obtained by employees with tertiary and higher education is greater than the one observed for individuals with primary education (women earn less than men). In all NACE branches but construction $\left(S E C_{-} D\right)$ and manufactoring $\left(S E C_{-} F\right)$ gender disparities are smaller than in mining and quarrying $\left(S E C_{-} C\right)$. It is also visible that in new EU member states the earning disparity is significantly smaller than for the old ones.

Models, denoted as 2 and 3 (in Table 4), are used to explain gender wage inqualities that are observed for different economic branches and job seniority groups. Both models are pretty similar in specification but they differ by dependent variable (that is either GPG or GPC) and function (linear ${ }^{17}$ or exponental). One may notice that the wage proportion $(W A G)$ does not influence pay differentials significantly, while the activity rate among women and feminization (masculinization) rates are significant variables. For all intervals describing length of service, the difference in earnings is bigger than the one observed for individuals who work less than 1 year. Analysing different NACE branches, ${ }^{18}$ we notice that branches with insignificant (in comparison to mining and quarrying, $S E C_{-} C$ ) discrepancies in wages include construction $\left(S E C_{-} D\right)$, wholesale and retail trade $\left(S E C_{-} G\right)$, financial intermediation $\left(S E C \_J\right)$ and real estate, renting, and business activities $\left(S E C_{-} K\right)$.

\section{Models Estimated on the Basis of LFS Data}

In regression models constructed for gender disparity measures (Table 4), a large part of the earnings gap is not explained by selected factors. Therefore we construct and estimate exponential models describing wages in Poland for all employees, as well as for men and women separately. Explanatory variables, that are selected arbitrarily for model construction are often used in research concerning wages, for instance Newell and Socha (2007). These variables describe respondent characteristics and employee firm characteristics. The selected factors that describe respondent attributes are:

1. Relationship with the head of the household (REL) dummy variable equals one for the household head.

2. Place of residence (RES) defined by five classes described by the number in thousands of inhabitants: cities with more than 100, cities with 50-100, 10-50, towns with 10 or less, using countryside as the referent category.

3. Marital status $(M A R)$ is a dummy variable equalling one if the respondent is married.

4. Occupation $(O C U)$ is described as army, managerial, professional, technical, clerical, sales \& services, farmers \& fishers, etc., industry workers, skilled workers, and unskilled workers as the referent category.

\footnotetext{
${ }^{17}$ Statistical test did not reject the hypothesis about the linear form of the model.

18 Data for the NACE branch L are not available.
} 
5. Education $(E D U)$ is described as university, post-secondary or vocational, general secondary, lower vocational, and preliminary or lower as the referent category.

6. Gender $(G E N)$ is a dummy variable equalling one for female.

7. Age $(A G E)$-measured quantitatively

Table 5 Parameter estimates for the model describing logarithm of monthly wages

\begin{tabular}{|c|c|c|c|c|c|c|c|c|c|c|}
\hline \multicolumn{2}{|c|}{ Explanatory variable } & \multicolumn{3}{|c|}{ Total: $N=7132$} & \multicolumn{3}{|c|}{ Women: $N=3400$} & \multicolumn{3}{|c|}{ Men: $N=3732$} \\
\hline & & Parameter & Error & & Parameter & Error & & Parameter & Error & \\
\hline \multirow[t]{3}{*}{$S E C$} & agriculture & 4.740 & 0.070 & $* * *$ & 3.478 & 0.112 & $* * *$ & 6.080 & 0.096 & $* * *$ \\
\hline & industry & 4.759 & 0.063 & $* * *$ & 3.584 & 0.087 & $* * *$ & 6.080 & 0.090 & $* * *$ \\
\hline & service & 4.725 & 0.062 & $* * *$ & 3.547 & 0.084 & $* * *$ & 6.044 & 0.089 & $* * *$ \\
\hline$O W N$ & private & 0.051 & 0.013 & $* * *$ & 0.093 & 0.019 & $* * *$ & 0.003 & 0.017 & \\
\hline \multirow[t]{4}{*}{$R E S$} & $>100$ thousands & 0.080 & 0.013 & $* * *$ & 0.084 & 0.019 & $* * *$ & 0.071 & 0.017 & $* * *$ \\
\hline & $50-100$ thousands & 0.024 & 0.019 & & 0.017 & 0.026 & & 0.030 & 0.025 & \\
\hline & $10-50$ thousands & 0.012 & 0.013 & & 0.036 & 0.020 & * & -0.016 & 0.017 & \\
\hline & $<10$ thousands & -0.033 & 0.020 & $*$ & -0.011 & 0.028 & & -0.060 & 0.026 & $* *$ \\
\hline$R E L$ & household head & 0.077 & 0.011 & $* * *$ & 0.068 & 0.017 & $* * *$ & 0.087 & 0.015 & $* * *$ \\
\hline$G E N$ & woman & -0.242 & 0.012 & $* * *$ & $\mathrm{X}$ & $\mathrm{X}$ & X & $\mathrm{X}$ & $\mathrm{X}$ & $\mathrm{X}$ \\
\hline \multirow[t]{2}{*}{$A G E$} & age & 0.101 & 0.003 & $* * *$ & 0.141 & 0.004 & $* * *$ & 0.043 & 0.004 & $* * *$ \\
\hline & $\operatorname{age}^{2}$ & -0.001 & 0.000 & $* * *$ & -0.002 & 0.000 & $* * *$ & -0.001 & 0.000 & $* * *$ \\
\hline$M A R$ & married & 0.004 & 0.012 & & -0.047 & 0.017 & $* * *$ & 0.112 & 0.017 & $* * *$ \\
\hline \multirow[t]{4}{*}{$E D U$} & ISCED_5_6 & 0.457 & 0.025 & $* * *$ & 0.570 & 0.039 & $* * *$ & 0.354 & 0.034 & $* * *$ \\
\hline & ISCED_4 & 0.291 & 0.020 & $* * *$ & 0.366 & 0.034 & $* * *$ & 0.222 & 0.024 & $* * *$ \\
\hline & ISCED_3 & 0.317 & 0.025 & $* * *$ & 0.412 & 0.038 & $* * *$ & 0.231 & 0.033 & $* * *$ \\
\hline & ISCED_2 & 0.170 & 0.019 & $* * *$ & 0.235 & 0.033 & $* * *$ & 0.128 & 0.022 & $* * *$ \\
\hline \multirow[t]{4}{*}{$S I Z$} & $<10$ employees & -0.079 & 0.018 & $* * *$ & -0.080 & 0.026 & $* * *$ & -0.135 & 0.023 & $* * *$ \\
\hline & 11-19 employees & -0.026 & 0.018 & & 0.021 & 0.027 & & -0.105 & 0.024 & $* * *$ \\
\hline & 20-49 employees & 0.020 & 0.016 & & 0.035 & 0.024 & & -0.024 & 0.021 & \\
\hline & >100 employees & 0.110 & 0.015 & $* * *$ & 0.119 & 0.022 & $* * *$ & 0.085 & 0.019 & $* * *$ \\
\hline \multirow[t]{9}{*}{ OCU } & army & 0.575 & 0.056 & $* * *$ & 0.894 & 0.410 & $* *$ & 0.500 & 0.057 & $* * *$ \\
\hline & managerial & 0.610 & 0.033 & $* * *$ & 0.611 & 0.049 & $* * *$ & 0.567 & 0.042 & $* * *$ \\
\hline & professional & 0.381 & 0.025 & $* * *$ & 0.382 & 0.032 & $* * *$ & 0.346 & 0.042 & $* * *$ \\
\hline & technical & 0.332 & 0.023 & $* * *$ & 0.341 & 0.031 & $* * *$ & 0.297 & 0.033 & $* * *$ \\
\hline & clerical & 0.199 & 0.023 & $* * *$ & 0.256 & 0.031 & $* * *$ & 0.085 & 0.035 & $* *$ \\
\hline & sales \& services & 0.136 & 0.022 & $* * *$ & 0.178 & 0.029 & $* * *$ & 0.057 & 0.034 & $*$ \\
\hline & farmers, fishers, etc. & 0.184 & 0.067 & $* * *$ & 0.380 & 0.174 & $* *$ & 0.099 & 0.068 & \\
\hline & industry workers & 0.185 & 0.019 & $* * *$ & 0.094 & 0.035 & $* * *$ & 0.161 & 0.024 & $* * *$ \\
\hline & skilled workers & 0.234 & 0.020 & $* * *$ & 0.196 & 0.039 & $* * *$ & 0.201 & 0.025 & $* * *$ \\
\hline \multicolumn{2}{|c|}{$\mathrm{R}^{2}$ adj. } & 0.9970 & & & $\mathrm{R}^{2}$ adj. & 0.997 & & $\mathrm{R}^{2}$ adj. & 0.332 & \\
\hline
\end{tabular}

Witkowska and Majka (2012)

*Denotes significance level $\alpha=0.1, * * \alpha=0.05$, and $* * * \alpha=0.01 ; \mathrm{X}$-denotes lack of variables 
To characterize employee firms or institutions, we apply the following variables:

1. Type of the enterprise ownership $(O W N)$ is a dummy variable equalling one for private and zero for public employers.

2. Size of employee's institution or firm (SIZ) is described as enterprises employing less than 10, 11 to 19,20 to 49, 50-100, and more than 100 employees. Enterprises employing 50 to 100 employees is the referent category.

3. Economic sector $(S E C)$ is described selectively as: agriculture, industry, and service, with other branches as the referent category.

Among the selected factors, only type of ownership does not influence wages in Poland (Table 5). The models show that women in Poland earn $21.5 \%$ less than men if monthly wages are considered. This may be caused either by the gender wage gap or by fewer working hours during a month. Heads of households earn more than others in the household. Married women earn less than unmarried ones, while married men earn more than the referent group. Respondents living in cities with over ten thousand inhabitants earn more than those living in the countryside, however the latter have higher monthly incomes than individuals living in cities with less than ten thousand inhabitants. The last statement is true for the total sample and the model constructed for men. Education positively influences wages and better education results in higher incomes. The highest monthly salaries are obtained by employees from the biggest enterprises (institutions). All occupational types generate higher salaries than those of unskilled workers, but for men, sales \& services and farmers \& fishers are insignificant.

\section{Conclusions}

The position of men and women still differs essentially throughout Europe and the situation of women has not improved quickly, regardless of the monitoring of gender equality by specially founded European institutions and their effectiveness. Gender disparities is a multidimensional problem which is relatively easy to discuss but difficult to describe and extremely difficult to overcome since the majority of the factors influencing gender inequalities are not measurable or even directly observable.

There are considerable differences inside the European Union that are connected with history, tradition, culture, and the welfare of EU member states. The European landscape with regard to gender equality has also changed because of recent enlargements. Most of the new EU member states have a quite distinct history of work and family policy and essential changes, not only in the political or economic arenas but also in the social sphere that have taken place during the last 20 years of economic transformation.

In the paper we discuss several aspects of gender disparities based on literature reviews and our own investigation. Our results confirm previous analyses that wage discrimination varies for different groups of employees and depends on the branch, age group, education, country, feminization of economic sectors, and activity of women in the labor market.

The gender pay gap is wider among employees earning higher wages since such relations are visible for higher job seniority groups and for better educated people who usually earn more than individuals from the referent groups. The increase in 
women's activity $(R A F)$ and feminization $(F E M)$ rates cause higher wage distortion. The labor market situation in Poland, a transitional economy, seems quite similar to the situation in other European Union member states in terms of factors that influence wages.

Open Access This article is distributed under the terms of the Creative Commons Attribution License which permits any use, distribution, and reproduction in any medium, provided the original author(s) and the source are credited.

\section{References}

Adamchik, V. A., \& Bedi, A. S. (2003). Gender pay differentials during the transition in Poland. The Economics of Transition, 11(4), 697-726.

Aigner, D. J., \& Cain, G. G. (1977). Statistical theories of discrimination in labor markets. Industrial \& Labor Relations Review, 30(2), 175-187.

Amuedo-Dorantes, C., \& de la Rica, S. (2005). The impact of gender segregation on male-female wage differentials: Evidence from matched employer-employee data for Spain, IZA Discussion Paper No. 1742. Bonn, Germany: Institute for the Study of Labor (IZA).

Arrow, K. J. (1973). The theory of discrimination. In O. Ashenfelter \& A. Rees (Eds.), Discrimination in labor markets. Princeton: Princeton University Press.

Arumpalam, W., Booth, A. L., Bryan, M. L. (2004). Is there a glass ceiling over Europe? exploring the gender wage gap across the wages distribution, IZA Discussion Paper No. 1373. Bonn, Germany: Institute for the Study of Labor (IZA).

Baldwin, M., \& Johnson, W. G. (1994). Labor market discrimination against men with disabilities. The Journal of Human Resources, 29(1), 1-19.

Becker, G. S. (1957). The economics of discrimination. Chicago: University of Chicago Press.

Bergmann, B. (1971). The effect of white incomes of discrimination in employment. Journal of Political Economy, 79, 294-313.

Bergmann, B. R. (1974). Occupational segregation, wages and profits when employers discriminate by race or sex. Eastern Economic Journal, 1(2), 103-110.

Bertrand, M., \& Mullainathan, S. (2004). Are Emily and Greg more employable than Lakisha and Jamal? a field experiment on labor market discrimination. The American Economic Review, 94(4), 991-1013.

Blau, F., \& Kahn, L. (2001). Understanding international difference in the gender pay gap. National Bureau of Economic Research. Working paper 8200, http://ww.nber.org/papers/w8200.

Blinder, A. S. (1973). Wage discrimination: reduced form and structural estimates. Journal of Human Resources, $8,436-455$.

Brainerd, E. (2000). Women in transition: Changes in gender wage differentials in eastern Europe and then Former Soviet Union. Industrial and Labor Relations Review, Vol. 54, No. 1 (Oct., 2000), pp. 138-162. Cornell University, School of Industrial \& Labor Relations. http://www.jstor.org/stable/2696036.

Cain, G. G. (1986). The economic analysis of labor market discrimination: A survey. In O. Ashenfeler, R. Layard (Ed.), Handbook of labour economics, vol. I (pp. 693-785). Elsevier Science Publishers BV.

Christofides, L. N., Polycarpou, A., Vrachimis, K. (2010). The gender wage gaps, 'sticky floors' and 'glass ceilings' of the European Union, IZA Discussion Paper Series, Discussion Paper No. 5044, Bonn, Germany: Institute for the Study of Labor (IZA), July 2010.

Commander, S., \& Dhar, S. (1998). Enterprises in the Polish Transition. In S. Commander (Ed.), Enterprise restructuring and unemployment in models of transition. Washington: The World Bank.

Cornish, M. (2007). Closing the global gender pay gap: securing justice for women's work. Comparative Labor Law \& Policy Journal, 28(2), 219-249.

Cotton, J. (1988). On the decomposition of wage differentials. The Review of Economics and Statistics, 70(2), $236-243$.

Daly, A., Kawaguchi, A, Meng, X., Mumford, K. (2006). The gender wage gap in four countries, IZA Discussion Paper No. 1921. Bonn, Germany: Institute for the Study of Labor (IZA).

Dijkstra, A. G. (2002). Revisiting UNDP's GDI and GEM: towards an alternative. Social Indicator Research, 57(3), 301-338.

Dijkstra, A. G., \& Hanmer, L. C. (2000). Measuring socio-economic gender inequality: towards an alternative to the UNDP gender related development index. Feminist Economics, 6(2), 41-75. 
Du Caju, P., Rycx, F., \& Tojerow, I. (2011). Inter-industry wage differentials: how much does rent sharing matter? The Manchester School, 79, 691-717.

European Commission Report on Equality between Women and Men (2008). http://europa.eu/legislation summaries/employment_and_social_policy/equality_between_men_and_women/c10167_en.htm.

Eurostat http://epp.eurostat.ec.europa.eu/

Fernández-Avilés, G., Montero, J. M., \& Witkowska, D. (2010). Gender wage gap in EU States. Application of taxonomic and spatial methods. In D. Witkowska \& K. Nermend (Eds.), Regional analysis: Globalization, integration, transformation (pp. 71-95). Szczecin: Wydawnictwo Uniwersytetu Szczecińskiego.

Fortin, N. M. (2005). General role attitudes and the labour-market outcomes of women across OECD countries. Oxford Review of Economic Policy, 21(3), 416-438.

Gannon, B., Plasman, R., Rycx, F., \& Tojerow, I. (2007). Inter-industry wage differentials and the gender wage gap: evidence from European countries. Economic and Social Review, 38(1), 135-155.

Gardeazabal, J., \& Ugidos, A. (2005). Gender wage discrimination at quantiles. Journal of Population Economics, (18), 165-179.

Grajek, M. (2001). Gender pay gap in Poland, Discussion Paper FS IV 01-13, Wissenschaftszentrum Berlin.

Hertz, T., Winters, P., de la O-Campos, A. P., Quiñones, E. J., Davis, B., Zezza, A. (2008). Wage inequality in international perspective: Effects of location, sector, and gender, ESA Working Paper No. 08-08.

Heshmati, A. (2004). A review of decomposition of income inequality, IZA, Discussion Paper No. 1221. Bonn.

Hunt, J. (1998). The transition in East Germany: When is a ten point fall in the gender pay gap bad news? Discussion Paper Series in Transition Economics, No.1805.

Keane, M. P., \& Prasad, E. S. (2006). Changes in the structure of earnings during the Polish transition. Journal of Development Economics, 80, 389-427.

Klasen, S. (1994). Human development and women's lives in a restructured eastern Block: Lessons from the developing world. In A. Schipke \& A. M. Taylor (Eds.), The economics of transition (pp. 253294). Berlin-Heidelberg: Springer-Verlag.

Klasen, S., \& Schuler, D. (2011). Reforming the gender-related development index and the gender empowerment measure: implementing some specific proposals. Feminist Economics, 17(1), 1-30.

Kot, S. M. (Ed.). (1999). Analiza ekonometryczna ksztattowania się płac w Polsce w okresie transformacji. Warszawa: PWN.

Lehmann, H., \& Wadsworth, J. (2001). Wage arrears and the distribution of earnings in Russia, IZA Discussion Paper 410. Bonn, Germany: Institute for the Study of Labor (IZA).

Livanos, I., \& Pouliakas, K. (2009). The gender wage gap as a function of educational degree choices in an occupationally segregated EU country, IZA Discussion Paper Series, Discussion Paper No. 4636, Bonn, Germany: Institute for the Study of Labor (IZA), December 2009.

Madden, J. F. (1975). Discrimination - a manifestation of male market power? In C. B. Lloyd (Ed.), Sex, discrimination, and the division of labor. New York: Columbia University Press.

Marshall, G. (1998). A dictionary of sociology, http://www.encyclopedia.com/doc/.

Matuszewska-Janica, A. (2011). Gender pay gap in the EU: Differences analysis by economic activity and education, paper presented at International Atlantic Economic Conference in Washington 2011.

Matuszewska-Janica, A., \& Witkowska, D. (2010). Inequality between the earnings of men and women in European Union versus structure of employment. In Metody Ilościowe w Badaniach Ekonomicznych Vol. XI/2. Wydawnictwo Szkoły Głównej Gospodarstwa Wiejskiego w Warszawie, Warszawa, p. 211221 (in Polish).

Matuszewska-Janica, A., \& Witkowska, D. (2011). Gender pay gap in EU: Selected factors analysis, paper presented at International Atlantic Economic Conference in Athens, March 2011.

McConnell, C. R., \& Brue, S. L. (1986). Contemporary labor economics. New York: McGraw Hill Book Co.

Neuman, S., \& Oaxaca, R. L. (2003). Estimating labor market discrimination with selectivity-corrected wage equations: Methodological considerations and an illustration from Israel, The Pinhas Sapir Center for Development Tel-Aviv University, Discussion Paper No. 2-2003, July 2003.

Neumark, D. (1988). Employer's discriminatory behavior and the estimation of wage discrimination. Journal of Human Resources, 23, 279-295.

Neumark, D., \& Stock, W. A. (1999). Age discrimination laws and labor market efficiency. Journal of Political Economy, 107(5), 1081-1125.

Newell, A., \& Barry, R. (2001). The gender pay gap in the transition from communism: Some empirical evidence. IZA Discussion Paper 268. Bonn, Germany: Institute for the Study of Labor (IZA).

Newell, A., \& Socha, M. W. (2007). The Polish wage inequality explosion, IZA Discussion Paper Series, Discussion Paper No. 2644, Bonn, Germany: Institute for the Study of Labor (IZA), February 2007. 
Ñopo, H., Daza, N., Ramos, J. (2011). Gender earnings gaps in the world, IZA Discussion Paper Series, Discussion Paper No. 5736, Bonn, Germany: Institute for the Study of Labor (IZA), May 2011.

Oaxaca, R. L. (1973). Male-female wage differentials in urban labour markets. International Economic Review, 14, 693-709.

Oaxaca, R. L., \& Ransom, M. R. (1994). On discrimination and the decomposition of wage differentials. Journal of Econometrics, 61, 5-21.

Olivetti, C., \& Petrongolo, B. (2008). Unequal pay or unequal employment? a cross country analysis of gender gaps. Journal of Labor Economics, 26(4), 621-654.

Pinto, B., Belka, M., Krajewski, S. (1993). Transforming state enterprises in Poland: Evidence on adjustment by manufacturing firms, Brookings Papers on Economic Activity, pp. 213-270.

Plasman, R., \& Sissoko, S., (2004). Comparing apples with oranges: Revisiting the gender gap in an international perspective, IZA Discussion Paper No. 1449. Bonn, Germany: Institute for the Study of Labor (IZA).

Plasman, R., Rycx, F., Tojerow, I. (2006). Industry wage differentials, unobserved ability, and rent-sharing: evidence from matched worker-firm data, 1995-2002. IZA Discussion Paper, No. 2387.

Simón, H. (2007). The gender pay gap in Europe: An international comparison with matched employeremployee data. Alicante: Universidad de Alicante.

Tansel, A., (2004), Public-private employment choice, wage differentials and gender in Turkey, IZA Discussion Paper 1262. Bonn, Germany: Institute for the Study of Labor (IZA).

Teichgraber (2012). European union labour force survey-annual results 2011, Eurostat Statistics in Focus 40/2012.

Thurow, L. C. (1975). Generating inequality. New York: Basic Books Inc. Publ.

Tzannatos, Z. (1999). Women and labor market changes in the global economy: Growth helps, inequalities hurt and public policy matters. The World Bank, Elsevier Science.

UNICEF (1999). Women in transition, the MONEE Project Regional Monitoring Report, No. 6, ICDC, Florence, Italy.

Weichselbaumer, D., Winter-Ebmer, R., Zweimüller, M. (2007). Market orientation and gender wage gaps: An international study. Department of Economics Johannes Kepler University of Linz.

Witkowska. (2012). Wage disparities in Poland: econometric analysis. Quantitative Methods in Economics, XIII(2), 115-124. SGGW Warszawa.

Witkowska, D., \& Majka, J. (2012). What determines wages in Poland?, paper presented at IAEC in Montreal 2012.

Witkowska, D., \& Matuszewska-Janica, A. (2012). Gender pay gap in the EU: Economic activity and job seniority, paper presented at IAEC in Montreal 2012.

Young, M. C., \& Wallace, J. E. (2009). Family responsibilities, productivity, and earnings: a study of gender differences among Canadian lawyers. Journal of Family and Economic Issues, 30(3), 305-319. 